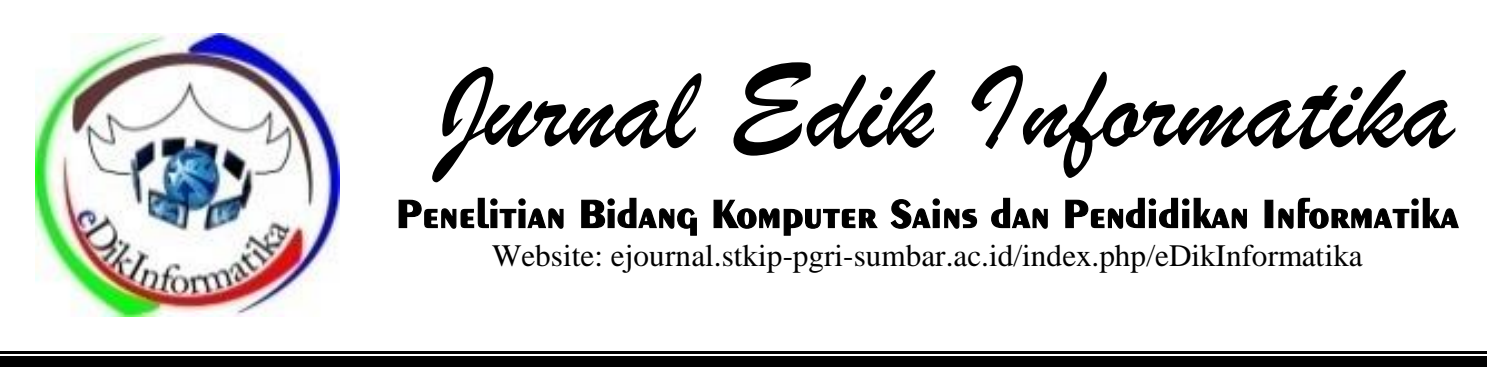

\title{
GAMBARAN MOTIVASI BELAJAR SIMULASI DIGITAL MENGGUNAKAN SMARTPHONE
}

\author{
Fadlul Amdhi Yul, Niska Ramadani ${ }^{2}$ \\ Universitas Dehasen Bengkulu \\ ${ }^{2}$ Akademi Sapta Bakti Bengkulu \\ fadlulamdhi@unived.ac.id
}

\begin{tabular}{|c|c|}
\hline INFO ARTIKEL & Abstract \\
\hline $\begin{array}{l}\text { Diterima: } \\
\text { 09 April } 2020 \\
\text { Direview: } \\
\text { 16 April } 2020 \\
\text { Disetujui: } \\
26 \text { Mei } 2020\end{array}$ & $\begin{array}{l}\text { This study focuses on the description of learning motivation through } \\
\text { smartphones on digital simulation subjects. The purpose of this study } \\
\text { is to find out how the picture of student motivation through } \\
\text { smartphones on digital simulation subjects in class X TKJ } 9 \\
\text { Muhammadiyah Bengkulu City. The method used in this research is } \\
\text { descriptive qualitative. The subjects of this study were } 15 \text { students of }\end{array}$ \\
\hline Keywords: & $\begin{array}{l}\text { class } X \text { TKJ. Data collection techniques are using observation, } \\
\text { interviews, documentation. The results of this study indicate that the }\end{array}$ \\
\hline $\begin{array}{l}\text { Motivasi, Belajar, } \\
\text { Descriptive } \\
\text { Qualitative }\end{array}$ & $\begin{array}{l}\text { use of a smartphone in school can be used as a support in learning } \\
\text { motivation, because a smartphone is needed as a tool used by } \\
\text { students to search for material, assignments given by teachers when } \\
\text { there are no learning books. However, the use of this smartphone } \\
\text { needs supervision from both parents and teachers at school, so that } \\
\text { it can help in increasing student motivation. }\end{array}$ \\
\hline
\end{tabular}

\section{PENDAHULUAN}

Dalam dunia pendidikan proses belajar-mengajar menjadi hal yang penting akan tetapi terdapat banyak hambatan yang dapat mempengaruhi pembelajaran, diantaranya adalah konsentrasi belajar tiap siswa yang berbeda-beda, sumber belajar hanya berasal dari guru, kurangnya perhatian siswa terhadap materi yang diajarkan oleh guru, dan siswa cenderung pasif dalam sesi tanya jawab. Masalah dalam proses belajar-mengajar lainnya seperti kurang maksimalnya penggunaan alat atau media pembelajaran yang dapat mendukung aktivitas belajar-mengajar serta kurang adanya upaya untuk mengembangkan metode pembelajaran, hal ini akan berdampak pada motivasi belajar siswa di mana siswa hanya berperilaku pasif dalam belajar. Motivasi belajar dapat membantu siswa dalam proses belajar mengajar di kelas. Motivasi belajar memberikan pengaruh positif dan signifikan terhadap proses belajar, yang berarti jika motivasi belajar siswa meningkat, maka siswa cenderung meningkatkan kompetensinya (Bakar, 2014).

Penerapan pembelajaran yang tepat dapat mempengaruhi motivasi dan hasil belajar siswa. Menurut Kurdi (2009), Student Centered Learning adalah pembelajaran yang berpusat pada aktivitas belajar siswa, bukan hanya pada aktivitas guru mengajar. Siswa harus 
lebih aktif dalam mencari informasiinformasi yang dibutuhkan dalam proses pembelajaran. Model pembelajaran ini menempatkan siswa yang aktif, mandiri, bertanggung jawab sepenuhnya atas pembelajarannya.

Berdasarkan hasil wawancara kepada siswa SMKS 9 Muhammadiyah Kota Bengkulu pada tanggal 15 April 2019. Diketahui bahwa masih banyak siswa yang kurang aktif, seperti guru sedang menjelaskan pembelajaran di dalam ruangan siswa sibuk dengan aktivitas lainnya, sibuk bermain dengan teman sebangku, ribut di kelas dan sibuk dengan kegiatan masing-masing seperti bermain smartphone saat proses pembelajaran berlangsung, sehingga mereka tidak memahami materi yang sudah diajarkan oleh guru. Hal tersebut dapat menimbulkan pengaruh kepada siswa, karena siswa sulit berkonsentrasi dan kurangnya motivasi pada saat proses pembelajaran di kelas, yang sedang berlangsung sehingga berdampak pada hasil belajar siswa.

Penggunaan teknologi di kelas dapat memberikan kesempatan untuk membuat instruksi yang berbeda dan mengubah kelas ke dalam lingkungan belajar yang dinamis, sehingga dapat menarik minat siswa terhadap proses belajar mengajar di kelas (Pitler, 2007), salah satu mata pelajaran yang banyak melakukan komunikasi dan melaksanakan instruksi yang berbeda adalah mata pelajaran simulasi dan komunikasi digital.

Menurut Cahya (2013), simulasi dan komunikasi digital adalah mata pelajaran yang membekali siswa agar dapat mengkomunikasi gagasan atau konsep melalui media digital. Dalam proses pembelajaran, siswa dapat mengomunikasikan gagasan atau konsep yang dikemukakan orang lain dan mewujudkannya melalui presentasi digital, dengan tujuan untuk menguasai teknik mengomunikasikan gagasan atau konsep.

Berdasarkan latar belakang topik penelitian ini adalah "Gambaran Motivasi Belajar Simulasi Digital Menggunakan Smartphone di Kelas X SMKS 9 Muhammadiyah Kota Bengkulu".

\section{METODE}

Metode penelitian yang digunakan adalah penelitian deskriptif kualitatif yaitu dengan melakukan wawancara langsung kepada siswa dan Guru di SMKS 9 Muhammadiyah Kota Bengkulu dengan menggunakan instrumen penelitian berupa kuesioner.

Pengumpulan data dilakukan melalui tahapan survei dan pengamatan langsung lokasi penelitian, penyusunan kuesioner, distribusi kuesioner, pengumpulan data, pengolahan hasil penelitian, analisis hasil penelitian, dan diskusi. Teknik pengumpulan data menggunakan observasi, wawancara, dan dokumentasi untuk mendapatkan data yang akurat dan benar.

\section{HASIL DAN PEMBAHASAN}

Setelah melakukan pengumpulan data di lapangan, dengan menggunakan teknik observasi, wawancara dan dokumentasi. Peneliti selanjutnya melakukan tahapan proses pengolahan dan analisis data. Data selanjutnya disajikan secara sistematis dan terarah sesuai dengan tujuan penelitian untuk mendeskripsikan tentang gambaran motivasi belajar melalui smartphone pada mata pelajaran simulasi digital kelas $\mathrm{X}$ TKJ.1 SMKS 9 Muhammadiyah Kota Bengkulu. Penelitian ini dilaksanakan pada tanggal 4 januari 2020 sampai 10 Februari 2020 
Tabel 1. Karakteristik Informan

\begin{tabular}{|c|c|c|c|c|c|}
\hline \multirow{2}{*}{ No } & \multirow{2}{*}{ Nama } & \multirow{2}{*}{$\begin{array}{l}\text { Umur } \\
\text { (tahun) }\end{array}$} & \multicolumn{2}{|c|}{ Jenis Kelamin } & \multirow{2}{*}{ Status } \\
\hline & & & Laki-laki & Perempuan & \\
\hline 1 & DP & 15 & - & $\sqrt{ }$ & Siswa Kelas x TKJ 1 \\
\hline 2 & $\mathrm{~K}$ & 16 & $\sqrt{ }$ & - & Siswa Kelas $\mathrm{x}$ TKJ 1 \\
\hline 3 & TW & 16 & - & $\sqrt{ }$ & Siswa Kelas x TKJ 1 \\
\hline 4 & LH & 16 & - & $\sqrt{ }$ & Siswa Kelas x TKJ 1 \\
\hline 5 & $\mathrm{~F}$ & 15 & $\sqrt{ }$ & - & Siswa Kelas x TKJ 1 \\
\hline 6 & LM & 16 & - & $\sqrt{ }$ & Siswa Kelas x TKJ 1 \\
\hline 7 & RI & 16 & $\sqrt{ }$ & - & Siswa Kelas x TKJ 1 \\
\hline 8 & FR & 15 & $\sqrt{ }$ & - & Siswa Kelas x TKJ 1 \\
\hline 9 & FA & 15 & - & $\sqrt{ }$ & Siswa Kelas x TKJ 1 \\
\hline 10 & FAC & 15 & $\sqrt{ }$ & - & Siswa Kelas x TKJ 1 \\
\hline 11 & $\mathrm{OL}$ & 17 & - & $\sqrt{ }$ & Siswa Kelas x TKJ 1 \\
\hline 12 & $\mathrm{~K}$ & 15 & - & $\sqrt{ }$ & Siswa Kelas x TKJ 1 \\
\hline 13 & $\mathrm{AKN}$ & 16 & - & $\sqrt{ }$ & Siswa Kelas x TKJ 1 \\
\hline 14 & $\mathrm{RC}$ & 15 & $\sqrt{ }$ & - & Siswa Kelas x TKJ 1 \\
\hline 15 & AP & 16 & $\sqrt{ }$ & - & Siswa Kelas x TKJ 1 \\
\hline
\end{tabular}

Sumber: Hasil Penelitian Tahun 2020

\section{Karakteristik Informan Penelitian}

Informan yang diwawancarai terdiri dari 15 orang siswa, siswa laki-laki berjumlah 7 orang dan siswi perempuan berjumlah 8 orang. Informan tersebut merupakan siswa pada kelas X TKJ 1 . Berdasarkan hasil penelitian yang dilakukan di lapangan terhadap siswa yang menjadi informan, berikut karakteristik informan dapat dilihat pada Tabel 1.

Dari tabel di atas karakteristik informan berbeda-beda, salah satu menjelaskan bahwa umur informan pada motivasi belajar siswa dikarenakan masing-masing informan tersebut dapat membantu peneliti dalam memperoleh data yang diperlukan. Dapat dilihat informan berdasarkan tingkatan umur yaitu berusia antara 15-17 tahun dengan umur informan yang paling rendah yaitu 15 tahun dan umur informan yang paling tinggi yakni 17 tahun. Hal ini menunjukkan umur informan berada pada masa remaja menuju dewasa.

Kemudian jenis kelamin menjelaskan bahwa jenis kelamin perempuan lebih banyak dibandingkan laki-laki. Laki-laki sebanyak 7 orang informan dan perempuan 8 orang informan. Selanjutnya yaitu status menunjukkan bahwa informan-informan tersebut merupakan siswa dari kelas $\mathrm{X}$ TKJ 1 SMKS 9 Muhammadiyah Kota Bengkulu.

\section{Gambaran Motivasi Belajar Melalui Smartphone}

Berdasarkan hasil wawancara diketahui bahwa siswa SMKS 9 Muhamadiyah Kota Bengkulu sangat termotivasi untuk belajar dengan menggunakan smartphone, hal ini dikarenakan dengan penggunaan smartphone dapat membantu siswa dalam proses pembelajaran serta meningkatkan motivasi siswa dalam belajar, siswa dapat mencari materi dan informasi tentang pembelajaran yang tidak tersedia dalam buku pembelajaran serta dapat membantu siswa dalam mencari informasi dan referensi dalam mengerjakan tugas. Hal ini berarti smartphone memiliki peran yang sangat penting bagi siswa dalam 
meningkatkan motivasi belajar, karena dengan smartphone dapat mendukung proses pembelajaran, interaksi antar guru dan siswa menjadi lebih aktif. Berikut contoh rangkuman hasil wawancara yang telah dilakukan:

Informan LH mengungkapkan bahwa:
"Dalam menyelesaikan tugas yang
diberikan oleh guru, saya mencari
sumber belajar melalui smartphone
sehingga membuat saya lebih mengerti
dan memahami materi pembelajaran”.

Informan D mengungkapkan bahwa:
"Dalam menunjang kegiatan belajar
saya lebih tertarik dengan adanya
bantuan media seperti smartphone yang
terkoneksi jaringan internet di sekolah
sehingga membuat saya cepat
memahami materi yang disampaikan
guru. "

Informan $T W$ mengungkapkan bahwa:

"Dalam menyelesaikan tugas yang diberikan oleh guru, saya selalu menggunakan smartphone untuk menjadi referensi dalam mencari materi yang sesuai."

Informan AKN mengungkapkan bahwa:

"Saya termotivasi dalam belajar dengan adanya bantuan smartphone, alasannya saya lebih mudah memahami yang ada di internet daripada penjelasan guru “

Informan Ki mengungkapkan bahwa:

"Jika saya menemui kendala dalam belajar saya selalu memanfaatkan smartphone sebagai malas untuk membandingkan materi yang diberikan oleh guru di sekolah"
Informan $R C$ mengungkapkan bahwa:

"Dalam menyelesaikan tugas yang di berikan oleh guru, kadangkala saya melihat tutorial atau langkah-langkah yang ada pada Youtube atau situs web yang ada di smartphone"

Berdasarkan wawancara di atas diketahui bahwa siswa klas X TKJ 1 sangat termotivasi dalam belajar simulasi digital dengan bantuan smartphone, karena dengan smartphone mereka lebih bersemangat untuk mengikuti pembelajaran.

Gambaran motivasi belajar melalui smartphone merupakan perkembangan peran smartphone yang tidak lepas dari gaya hidup aktivitas manusia pada zaman modern saat ini. Smartphone dapat memberikan dua dampak dalam kehidupan siswa-siswa saat proses pembelajaran berlangsung. Pertama ada dampak positif, yaitu di mana ponsel membawa keuntungan bagi siswa saat proses pembelajaran berlangsung, karena lebih mudah untuk membantu siswa mencari tugas, materi pembelajaran yang tidak bisa dipahami di dalam buku. Kedua adalah dampak negatif bagi siswasiswa, di mana smartphone membawa pengaruh yang tidak baik bagi siswa saat proses pembelajaran berlangsung di mana siswa sibuk bermain smartphone ketika dalam proses pembelajaran berlangsung.

Motivasi belajar merupakan sesuatu keadaan yang terdapat pada diri seseorang individu di mana ada sesuatu dorongan untuk melakukan sesuatu untuk mencapai tujuan, motivasi dapat mengubah energi pribadi dalam diri seseorang yang ditandai timbulnya dengan efektif (perasaan) dan reaksi untuk mencapai tujuan pembelajaran.

Berdasarkan hasil wawancara yang dilakukan pada 15 orang siswa kelas X.1 SMKS 9 Muhammadiyah Kota Bengkulu 
diketahui bahwa siswa memiliki ketekunan dalam menyelesaikan tugas simulasi digital, seperti selalu mengerjakan tugas yang diberikan oleh guru dengan baik dan tepat waktu. Tetapi ada juga siswa memiliki kendala dalam mengerjakan tugas simulasi digital seperti kurangnya jaringan untuk mengakses internet, karena membutuhkan jaringan yang kuat dalam untuk akses internet, sehingga diperlukan adanya media yang mampu menunjang siswa untuk mengakses internet tanpa terhalang kondisi yang buruk. Beberapa siswa yang termotivasi saat menggunakan smartphone ketika proses mempelajari simulasi digital berlangsung karena dengan mengakses internet, mereka lebih mudah dan banyak mencari tahu segala hal tentang pembelajaran simulasi digital di internet melalui browsing, google, chrome dan lainnya. Penggunaan smartphone melalui internet, dapat memudahkan siswa dalam mencari materi yang diajarkan oleh guru sehingga siswa dapat termotivasi melalui smartphone ketika dalam proses belajar berlangsung dilaksanakan.

Peneliti menemukan adanya pengaruh smartphone dalam proses pembelajaran materi jaringan dasar kelas $X$ di SMKS 9 Muhammadiyah Kota Bengkulu antara lain:

1. Siswa mampu bekerjasama dalam menyelesaikan tugas yang diberi oleh guru.

2. Siswa dapat mengakses smartphone untuk mencari materi pembelajaran yang belum mereka ketahui.

3. Siswa dapat terhibur dengan fiturfitur yang ditawarkan pada jenisjenis smartphone yang mereka miliki.

Melalui smartphone siswa, mereka dapat menyimpan data yang telah mereka temukan dan dapat dibuka kembali untuk mereka baca. Peneliti menyimpulkan bahwa adanya motivasi belajar siswa dalam menggunakan smartphone.

Hasil penelitian ini sejalan dengan hasil penelitian yang teliti oleh Gardenia Augusta (2018) yang menegaskan bahwa penggunaan smartphone pada siswa memiliki pengaruh terhadap motivasi belajar, di mana dewasa ini cenderung selalu menggunakan smartphone mereka dibandingkan membaca buku. Smartphone hanya digunakan sebatas browser data, internet, dan game. Realitas ini serupa dengan hasil penelitian Satriawanati (2017) bahwa anak menjadi terabaikan lewat kasih sayang palsu yang diberikan orang tua dengan cara memberikan dan menyediakan fasilitas kepada anak mereka berupa smartphone, bermain game, menonton TV secara berlebihan. Hal ini membuat anak menjadi malas belajar, lebih menyukai yang instan bahkan bisa membuat hasil belajar menjadi rendah.

\section{KESIMPULAN}

Berdasarkan hasil penelitian mengenai gambaran motivasi belajar melalui smartphone pada mata pelajaran simulasi digital di SMKS 9 Muhammadiyah Kota Bengkulu, dapat diambil kesimpulan bahwa sekitar 70\% siswa kelas $X$ di SMKS 9 Muhammadiyah Kota Bengkulu termotivasi saat belajar. Hasil penelitian ini menunjukan bahwa tingkat motivasi menggunakan smartphone sudah sangat baik. Hasil wawancara kepada siswa dideskripsikan bahwa gambaran motivasi belajar menjelaskan beberapa hal, yaitu: Informan memiliki keinginan untuk membaca ulang, aktif dalam pembelajaran sehingga bisa saling membantu teman yang lain melalui smartphone.

Motivasi memiliki kedudukan yang penting dalam mencapai tujuan pembelajaran yang telah ditetapkan. Munculnya motivasi tidak semata-mata 
dari diri siswa sendiri tetapi guru harus melibatkan diri untuk memotivasi belajar siswa. Adanya motivasi akan memberikan semangat sehingga siswa akan mengetahui arah belajarnya. Motivasi belajar dapat muncul apabila siswa memiliki keinginan untuk belajar. Oleh karena itu motivasi baik intrinsik maupun ekstrinsik harus ada pada diri siswa sehingga tujuan pembelajaran yang sudah dirumuskan dapat tercapai secara optimal.

\section{DAFTAR PUSTAKA}

Augusta, G. 2018. Pengaruh Penggunaan smartphone Terhadap Prestasi Belajar Mahasiswa Melalui Motivasi Belajar Mahasiswa. Skripsi. Yogyakarta : Universitas Sanata Dharma.
Bakar. (2014). The effect of Learning Motivation on Student's Productive Competencies in Vocational High School, West Sumatra. International Journal of Asia Social Science. 4(6):722-732.

Cahya, Eko S, H., dkk. (2013). Simulasi Digital Jilid 1. Jakarta: Kementerian Pendidikan \& Kebudayaan.

Kurdi, (2009). Penerapan Student Centrad Learning dari Centered Learning Mata Ajar Ilmu Kesehatan pada Program Studi Penjaskes. Jurnal Forum Kependidikan. 28(2): 108-11.

Satrianawanti. (2017). Dampak Penggunaan Handphone Terhadap Aktivitas Belajar Siswa Sekolah Dasar. Jurnal Profesi Pendidikan Dasar. 4(1):54-61. 